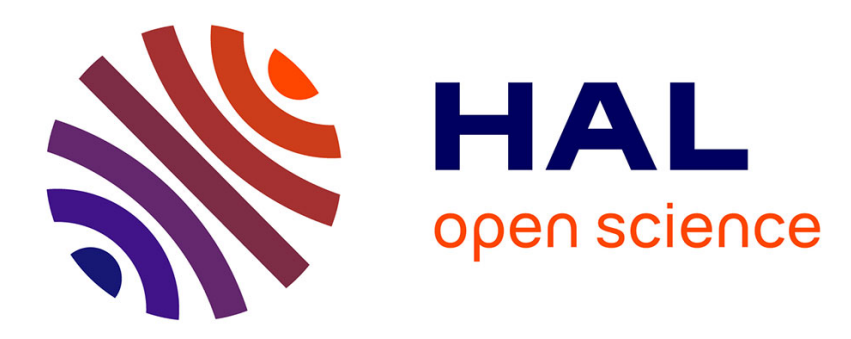

\title{
Institutional Context, Organizational Resources and Strategic Choices
}

Rainer Eising

\section{To cite this version:}

Rainer Eising. Institutional Context, Organizational Resources and Strategic Choices. European Union Politics, 2007, 8 (3), pp.329-362. 10.1177/1465116507079542 . hal-00571748

\section{HAL Id: hal-00571748 \\ https://hal.science/hal-00571748}

Submitted on 1 Mar 2011

HAL is a multi-disciplinary open access archive for the deposit and dissemination of scientific research documents, whether they are published or not. The documents may come from teaching and research institutions in France or abroad, or from public or private research centers.
L'archive ouverte pluridisciplinaire HAL, est destinée au dépôt et à la diffusion de documents scientifiques de niveau recherche, publiés ou non, émanant des établissements d'enseignement et de recherche français ou étrangers, des laboratoires publics ou privés. 


\section{EUP}

European Union Politics

DOI: $10.1177 / 1465116507079542$

Volume 8 (3): 329-362

Copyright@ 2007

SAGE Publications

Los Angeles, London, New Delhi and Singapore

\section{KEY WORDS}

- access and influence

- comparative politics

- European Union

- interest groups

- organization theory

- political exchange

\section{Institutional Context,}

Organizational Resources and Strategic Choices

\author{
Explaining Interest Group Access in the \\ European Union
}

Rainer Eising

Friedrich-Schiller University, Jena, Germany

\begin{abstract}
Drawing on a survey of 800 business associations, the article seeks to explain why interest groups lobby the EU institutions and what groups maintain contacts with them. Rooted in organizational theory, it argues that four main dimensions influence access patterns - institutional context, resource dependencies, interest group organization, and strategic choices. The empirical analysis demonstrates that all dimensions are relevant. Nonetheless, contacts between EU policy-makers and interest groups display only a few general traits: they are shaped by the political mobilization of groups in response to EU regulation, the division of labour among EU and national associations and the importance of organizational resources. Beyond these general influences, the interactions vary profoundly in the segmented institutional context.
\end{abstract}




\section{Introduction}

Relations among European Union (EU) institutions and interest groups are a major element in the governance of the EU. European Commission officials discuss EU policies as frequently with interest organizations as with members of the European Parliament (EP) or the Council of the EU (Hooghe, 2001: 64). In fact, the EU bureaucrats are more often in touch only with national civil servants than with business interest groups. Many scholars consider the access of interest groups to the EU institutions to be important because systematic variations in these access patterns can result in biased politics (Coen, 1998; Cowles, 2001). It is therefore puzzling that comprehensive studies of these interactions are rare (but see Beyers, 2002; Bouwen, 2002; Mahoney, 2004). EU interest group studies tend to concentrate on EU interest organizations rather than national groups, look into distinct issue areas and at specific EU institutions, analyse organizations from just one member state, or focus on the domestic level in EU policy-making (Dür and De Bièvre, 2007; Eising, 2006; Woll, 2006).

As a result, no coherent picture has yet emerged as to what determines the access of interest groups to the EU institutions. ${ }^{1}$ Vivien Schmidt (1999) highlights the importance of systemic factors, pointing especially to the mode of interest intermediation that is prevalent in a political system. By contrast, Gerda Falkner (2000) concentrates on sectoral characteristics. She maintains that EU interest intermediation needs to be studied sector by sector. Finally, Pieter Bouwen (2002) stresses the organizational features of interest groups, particularly emphasizing their control of policy information.

Each of these studies has great merits in pointing out major elements of the political exchanges in the EU. But none of them controls for the other potentially important dimensions. Addressing this shortcoming, I seek to integrate them in a consistent explanation of interest group access to the EU institutions, thus aiming at the consolidation and, when necessary, modification of our established understanding. Drawing on the organizational theory of resource dependencies, I suggest that the EU institutional context, the resource dependencies between state and business, as well as the interest groups' structures and strategies shape access to EU policy-makers. The empirical evidence is based on a cross-sectoral survey of 800 German, UK, French and EU business associations and thus covers an important portion of the EU interest group population.

The principal conclusion is that all dimensions must be taken into account. Focusing on just one of them leaves out important facets of the access patterns. Moreover, I single out the general determinants of interest group access in the EU. These are the division of labour among European and 
national associations; the organizational resources of interest groups; and their political mobilization when they find the EU institutions to be important for the representation of their interests. The effects of all other factors vary among the EU institutions because of the segmented institutional context. These variations point to different consultation criteria of the EU institutions and suggest that the bureaucratic rationality of the Commission diverges significantly from the susceptibility of the Parliament to public debate. They also indicate that domestic modes of interest intermediation are less important for obtaining access to EU policy-makers than has been suspected.

The article is structured as follows. First, I discuss the rationale for studying the access of business interests to the EU institutions and argue that institutional context, resource dependencies, organizational structures and strategic choices shape access patterns. After presenting the data and testing the hypotheses by means of ordered logit regressions, I provide the empirical results. The conclusion summarizes the main findings and discusses their implications for the study of interest groups in the EU.

\section{Towards an explanation of interest group access in the EU}

I define access as the frequency of contacts between interest organizations and EU institutions. These contacts range from informal bilateral meetings with EU officials and politicians to institutionalized committee proceedings. This definition emphasizes that the organizations actually acquire contacts and do not just aspire to them or forgo their access opportunities. Obviously, this access concept excludes indirect ways and means to exert influence on policymakers via the public or the media. Nonetheless, it is well suited to studying the representation of interests by business, which is said to pursue insider strategies and seek face-to-face negotiations with policy-makers (Walker, 1991; Wilson, 1973).

Business associations seek access for a variety of reasons. On the one hand, they cannot be sure that the EU institutions anticipate their interests when devising policy proposals so that, in order to secure a final policy outcome, they need to inform the institutions about their policy preferences and about the merits and drawbacks of alternative courses of action. On the other hand, seeking to survive as organizations, EU lobbying may serve to maintain or expand their membership and financial status, secure the attention and support of EU policy-makers, or obtain a favourable public opinion climate (see Lowery, 2007: 48).

However, having access does not imply that their contacts have an effect on EU policies (Meynaud and Sidjanski, 1971: 465; Beyers, 2002). In fact, the 
more groups are present in the European policy space, the less likely it is that any of them will have a significant impact on political outcomes. In crowded policy arenas, policy-makers may be able to play off interest groups against each another. More generally, EU policy-makers may prefer to decide against business interests and rather pursue their own policy agenda. And, in those cases in which they include business concerns in EU legislation, this may simply be the result of convergent but independent policy preferences. In some instances, they might even co-opt interest organizations in order to pursue their own goals.

In short, access is not equal to influence. Nonetheless, many groups find these contacts necessary in their efforts to have a say in EU policies, given that these tend to require a lot of detailed policy input and are often the outcome of lengthy debates between EU policy-makers, national administrations and interest organizations. It is therefore hardly surprising that interest groups complain when they are shut out from EU decision-making. ${ }^{2}$ More generally, Edgar Grande (1996) suggests that the temporary closure of decision-making processes can enable policy-makers in the EU to fence off interest group demands. In sum, those organizations that are continuously in touch with EU officials and politicians are better informed about EU policy-making and better able to voice their general concerns and specific proposals than are other groups. Therefore, studying access helps to identify important determinants of the European political process and major characteristics of those organizations that assume important positions in EU policy networks, in part acting as gate-keepers to the EU institutions.

I argue political access results from the institutional context, resource dependencies and associational structures and strategies.

\section{The institutional context}

The institutional context defines the opportunities for getting in touch with EU decision-makers (Meynaud and Sidjanski, 1971: 468; Marks and McAdam, 1996; Pollack, 1997; Lowery, 2007). Notably, three elements of the EU institutional setting shape the access of interest groups: its segmentation into three pillars, the allocation of powers to its institutions, and their vertical and functional differentiation. Because the first pillar, the European Communities (EC), encompasses the vast majority of the Union's policies, my subsequent analysis concentrates on this pillar. The focus is on legislative lobbying at EU level. Legal strategies involving the European Court of Justice or activities in the member states will not be considered in detail. Nor will access to the Economic and Social Committee be analysed because it is of only marginal importance for the representation of interests in the EU. 
In the EC pillar, the European Commission is considered to be the most important contact partner of interest groups (Mazey and Richardson, 2002). Its legal monopoly over policy initiation grants it a crucial role in agendasetting and policy formulation. Many interest groups emphasize the difficulty of obtaining substantial modifications of a Commission proposal once it has been presented to the Parliament and the EU Council (Meynaud and Sidjanski 1971: 465). As the 'guardian of treaties', the Commission also monitors compliance with Community law. Even though the Commission exerts its powers collectively, it is rarely approached as a collegiate body. Rather, interest groups maintain relations with its Directorates-General, each of which is responsible for specific policy areas.

Over time, the European Parliament has acquired substantial legislative powers. Nonetheless, even today, it is often held to be less important to interest groups than the Council or the Commission because its influence varies greatly according to the issue and decision-making procedure at hand. In general, the EP is considered to represent supranational interests in EU policy-making. But, being elected by national voters, the members of the European Parliament (MEPs) are more amenable than the Commission to national interests and more open to diffuse interests, including those representing the environment, consumers or large groups such as the unemployed and pensioners. In general, the heads of the Standing Committees and the rapporteurs who are responsible for drafting the policy dossiers are the most important addressees for interest group demands.

Owing to its decisive position, the EU Council would seem to be a highly relevant contact for interest groups. The meetings of the Council of Ministers are prepared by its administrative machinery, the Committee of Permanent Representatives (Coreper) and the Council working groups, which are composed, for the most part, of national experts. Given its relatively few meetings and its composition of national delegates, the Council is rarely lobbied in Brussels. Rather, domestic interest groups tend to address their concerns to national government departments. Although the Council's policy positions evolve along national lines, in part as a consequence of pressure by domestic interests, the Council is more removed from interest group pressure. Not only does it comprise the heads of state and government, thus representing the general interest to a larger degree, but it also meets formally only once every six months, lessening its impact on the minutiae of day-to-day politics in the EU. Therefore, the analysis concentrates on the EU Council.

Given the differentiation within these institutions, it can be expected that interest organizations have more frequent interactions at the working level than with the political leaders, partly because European integration consists largely of technical details (Mazey and Richardson, 2002: 136). The desk 
officers in the Commission, the Council working groups and also the parliamentary committees are responsible for drafting policy proposals or sorting out their details. Accordingly, the bureaucratic staff depend heavily on information and support. In contrast, the Commissioners and the ministers usually do not pay attention to every policy detail but focus on those aspects that are contested or deemed to be crucial. As far as interest groups are concerned, lobbying them aims either at establishing broad policy principles, raising the stakes in favour of a specific policy alternative, or revising decisions that were taken earlier in the policy process. Hence, less frequent access to these leaders does not imply that these contacts are less important than those at the working level.

The EU multi-level system offers multiple opportunities for interest organizations to represent their interests: 'interest groups at any territorial level are free to lobby government at any number of levels' (Constantelos, 1996: 30). However, it is unlikely that EU associations and domestic groups will be evenly represented at each level of government. These organizations are tied to their members and embedded in the context in which they emerged. They depend on routine exchanges with their partners from whom they extract resources (see Wilson, 1973). Hence, it can be expected that their location in the multi-level institutional setting shapes their political activities. EU business associations tend to organize member firms and associations that are located within the EU member states. This is important to the EU institutions, which have repeatedly stated that they do not wish to negotiate separately with a large number of domestic interest organizations. In contrast, national associations organize members and represent their interests at the domestic level. To them, EU-level activities are an additional task. Because they must manage scarce resources, they tend to rely on EU associations for the representation of their interests at the EU level (Bennett, 1997). Only if the EU regulation has an important impact on their members, if their division of labour with those EU associations that are supposed to represent them in EU politics is unsatisfactory, or if the terms of EU policy implementation on domestic grounds have to be worked out, will they extend their activities to the EU level. Hence, EU associations have more contacts with EU institutions than do national associations.

Hypothesis 1.1: EU associations have more frequent access than do national associations.

Being embedded in domestic contexts, it is plausible that national modes of interest intermediation have an impact on the access patterns of national interest organizations. Even in the era of economic globalization, many authors find that these factors do not simply fade away and are relatively 
stable over time (e.g. Hollingsworth and Boyer, 1997; Hall and Soskice, 2001; Lehmbruch, 1991), so that they continue to explain the interaction among national institutions and domestic interest organizations. I therefore now discuss the national state-business relations that are prevalent in France, the United Kingdom and Germany.

Time and again, France has been labelled étatiste (see Schmidt, 1999). A high degree of centralization enables state actors in pursuit of the public good to impose their decisions on private parties in a non-cooperative fashion. Associations do not play a major role when policies are formulated even though they may come back in when policies are implemented. The United Kingdom is as centralized as France but it is not rooted in the same statist tradition (Dyson, 1980). The UK government generally strives for consensus with interest groups but has a strong capacity to exclude them from political processes. Thus, being sometimes subject to stop-go consultation in the UK's pluralism, interest groups enjoy relatively good access to their government (Cowles, 2001). In Germany, state powers are more dispersed and interlocked than in France or the UK, so that German associations have more access opportunities. In addition, state institutions have a distinct preference for associational self-regulation. In Germany's corporatism, a substantial number of associations have developed negotiation capacities and co-regulatory skills. They have routine access to the government and are regarded as legitimate spokespeople for their domains (Streeck, 1999). Translating these patterns to the EU level means:

Hypothesis 1.2: Corporatism supports better access to the EU institutions than does pluralism, which leads to better access than does statism.

However, the relation among domestic modes of interest representation and political activities in the EU is not yet well understood so that there are two major contenders to Hypothesis 1.2. First, some authors argue that $\mathrm{em}$ beddedness in domestic policy networks is decisive for the adaptation of national actors to the EU. On the one hand, those associations that enjoy excellent access to domestic institutions might continue to rely on their established national channels of communication and influence. On the other hand, those associations that are excluded from domestic policy networks might seek compensation at EU level (Beyers, 2002). Accordingly, the correlation between national and EU-level contacts should be negative.

Second, Vivien Schmidt (1999) and Maria Green Cowles (2001) suggest that the degree of fit between the EU and the national modes of interest intermediation matters most. According to this logic, those associations that are well acquainted with the EU mode adapt more easily to EU-level interest representation than do groups that have been socialized in a different setting. 
Both authors find that pluralism prevails in the EU. Accordingly, associations socialized in a pluralistic context should find it easier to extend their practices to the EU level than associations with a corporatist or a statist background.

\section{Resource dependencies}

Contacts are rooted in resource dependencies between state institutions and interest groups. Hence, access cannot be fully understood without an exchange paradigm. On the one hand, Majone (1996) has pointed out that business bears the costs or obtains the benefits of EU regulation provided by the EU institutions. However, EU regulation needs to be apparent to the interest organizations if it is to trigger efforts to access the EU institutions. Therefore, I rely on the importance that associations ascribe to the EU institutions as an indicator of their perception of EU regulation. If the associations or their members are exposed to a higher degree of EU regulation, they are likely to attach greater relevance to the EU institutions for the representation of their interests and undertake greater efforts to access them.

Hypothesis 2.1: The more relevant that associations find the EU institutions for the representation of their interests, the more they tend to seek and have contacts with the EU institutions.

On the other hand, EU regulation generates a huge demand for policy information. Some authors claim that this information is the most important currency in European governance (Bouwen, 2002; Crombez, 2002). Given their limited resources, the EU institutions are in need of information that enables them to devise policy proposals that solve the problems at hand, can be administered in the member states and can win a sufficient majority among EU legislators (Mazey and Richardson, 2002: 148; Meynaud and Sidjanski, 1971: 552). Obviously, they have recourse to several sources of information, such as international organizations, member state administrations, thinktanks, interest organizations and scientific experts. The incentives of actors to withhold or manipulate information are reduced by this broad variety of sources as well as by the fact that many of them are involved in a series of policy games. Their reputations might suffer if they proved to be unreliable. The policy information of business interests is deemed essential in the areas of market integration and regulation, standard-setting and external commercial policy. Here, business interests command specific and private information about the likely economic and technical effects of EU programmes, their repercussions on domestic law and the political responses of their members.

Hypothesis 2.2: The more policy information associations can deliver, the better is their access. 
EU institutions depend on interest groups not only for their information but for a variety of further exchange goods. In that respect, the consent of interest groups to EU policies and their ability to enhance the legitimacy of these policies seem crucial. EU institutions need the consent of business interest organizations if these are able to forestall an agreement at EU level or impede its implementation. Here, I consider the impact of the structural economic power of business on its ability to veto EU policies. Given the strong focus of the EU on market-making and market-correcting policies, the internationalization and economic weight of business would seem to be as important as policy information. Internationalization increases the veto power of business because producers operating in international markets can more credibly threaten to shift investments than can producers that are nested in domestic markets.

Hypothesis 2.3: A higher degree of internationalization increases the number of contacts.

Economic weight, which indicates the number of employees that the members of an association have, is a proxy for the relevance of these firms in the economy. The greater the economic weight of firms, the greater are 'the public consequences of [their] discretionary decisions in the market' (Lindblom, 1977: 171) and the more will political actors be interested in the functioning of the economic domains that business associations represent. Needless to say, economic clout, investment decisions and employment effects cannot be invoked for each and every policy issue and their importance varies across time (Vogel, 1987).

Hypothesis 2.4: Greater economic weight secures better access to EU policymakers.

In recent years, EU institutions have also come to stress the contribution of civil society - in which the Commission counts business interest groups - to the legitimacy of European governance. Membership density indicates to what extent an association mobilizes its potential members. The more potential members an association organizes, the more it can claim to be representative of its domain. This should improve its access because it increases the democratic legitimacy of EU policies (European Commission, 2002a).

Hypothesis 2.5: A higher membership density improves access to EU institutions.

\section{The organization of business interest associations}

Business interest associations define, aggregate and promote the political interests of a distinct group of producers or employers (Schmitter and Streeck, 1981: 33). They exchange resources with their members and with state 
institutions to ensure their continuation and to enhance their autonomy (Wilson, 1973). Their organizational structures contain the core answers to the questions of how to deal with the demands of their members and of state institutions (Truman, [1951]1993: 113). Several interest group studies that are rooted in organizational theory (Grote and Lang, 2003; Knoke, 1990; Schmitter and Streeck, 1981; Walker, 1991; Wilson, 1973) have highlighted the relevance of two key elements in organizational structures: organizational domains and organizational resources.

The organizational domain has a strong impact on the collective activity of associations. Separating those 'members and interests that are admitted into the association, from others that are excluded' (Schmitter and Streeck, 1981: 122), it delimits the sectoral scope of the association. The size of the sector domain has two opposing effects on access to political institutions. A broader sector domain tends to enhance the relevance of an association to policy-makers but decreases its capacity for collective action. Ceteris paribus, a narrow sub-sector domain is associated with a small number of policy issues and members, which allows the association to pursue its members' interests vigorously without much need for internal compromise. However, although its capacity for collective action may be high, an association with a narrow domain may turn out to be irrelevant to policy-makers. In contrast, a broader sector or cross-sector domain increases the number of members and policy issues the association must cope with such that the increased heterogeneity of member interests may render the definition of collective goals more difficult. Nonetheless, EU institutions have stated that they prefer to negotiate with broad-based associations because this facilitates political reforms and relieves them of the task of dealing with a vast array of narrow claims (European Commission, 2002a).

Hypothesis 3.1: A broader sector domain improves access to EU institutions.

Furthermore, different actors may be eligible to join an association. To some extent, the types of members indicate the position that interest organizations assume in the associational system. Associations with a direct membership of entrepreneurs, business organizations and firms form the bottom layer. They tend to have narrow domains and aggregate interests at a relatively low level. By contrast, federations organize other associations and are located at the higher echelons of the associational population, which should improve their access to EU policy-makers. In addition, several business associations allow for the membership of both firms and associations. Firms thereby avoid the filtering of their interests in lower-order associations. In turn, mixed membership groups obtain additional resources from the firms. Therefore, they should have better access than federations. 
Hypothesis 3.2: Mixed membership groups have better access than federations, and these have better access than direct membership groups.

To ensure their survival and maintenance, associations need a more or less stable supply of resources from their members and their environment (Wilson, 1973: 30). Financial resources are a major prerequisite for their activities. A larger income allows them to develop an elaborate division of labour, with a permanent staff (Knoke, 1990: 76). Bureaucratization and specialization then enable them to pursue their objectives more effectively. They also make for the development of long-term goals, which can be conducive to the build-up of continuous relations with state authorities.

Hypothesis 3.3: A larger budget improves access to the EU institutions.

To extract resources from their members, associations offer them incentives (Knoke, 1990; Schmitter and Streeck, 1981; Wilson, 1973). Business associations usually provide some collective goods (i.e. they seek to affect public policy-making or govern market exchanges) and some selective goods (i.e. services) to their members. Hence, the main rationale of many business interest groups is not interest representation but service provision. The representation of interests may in fact be only a by-product of these other activities (Olson, 1965). However, empirical studies of EU interest groups suggest that service provision is far less important than interest representation in EU interest intermediation (Greenwood and Aspinwall, 1998). Hence, specializing in interest representation should equip groups with greater capacities to access political institutions.

Hypothesis 3.4: Specialization in interest representation improves access to EU institutions.

\section{The strategic choices of interest organizations}

Even though their activities are in part determined by their organizational domain and by their resources, associations have some latitude left in the choice of their strategy of interest representation. Here, many studies distinguish between insider and outsider strategies (Walker, 1991). However, the empirical analysis indicates that business associations rely on three strategies to represent their interests in the EU: to different degrees, they pursue insider, outsider and nationalistic strategies.

Many business associations regard close relations with EU officials and parliamentarians as important assets and seek to get accepted as legitimate spokespeople for their domains (Wilson, 1973: 314-16). Their insider strategy matches the need of the EU institutions for policy information and support. 
Hypothesis 4.1: An insider strategy increases the number of interactions with EU institutions.

Other associations resort to the media and to the public in order to represent their interests. Occasionally, well-timed public pressure may improve their access and influence. However, frequent campaigns against EU decisions seem incompatible with an insider strategy. It is therefore not likely that business associations will resort to an outsider strategy if they attach great value to close relationships with state institutions (Wilson, 1973: 285).

Arguably, the effects of a campaign depend on whether it is run by EU associations or by national groups. Because the European public is structured along national borders, national groups tend to mobilize distinct national publics. Their efforts are directed at national institutions even if they result from EU policies (Imig and Tarrow, 2001). In contrast, EU associations seek to mobilize a wider 'European public' or audiences from several member states, which should have a more favourable effect on their access to the EU institutions.

Hypothesis 4.2: An outsider strategy reduces the number of contacts with EU institutions. EU associations pursuing an outsider strategy have better access than do national associations with such a strategy.

Finally, some associations thrive on the heterogeneity of the EU member states. To them, the nationality of EU officials and politicians as well as their language is of utmost importance in selecting contact partners. To a lesser extent, they select their contact partners on the basis of party affiliation and on the basis of personal acquaintance. This nationalistic strategy limits the number of contact partners in the EU because it relies on coalition-building with like-minded national actors and is rooted in deeply ingrained national differences among EU politicians and officials that are not conducive to EU problem-solving.

Hypothesis 4.3: A nationalistic strategy reduces access to EU institutions.

Table 1 summarizes these hypotheses and presents the operational definitions of the variables. ${ }^{3}$

\section{The empirical analysis}

\section{Research design and data}

These hypotheses will be tested in a study that combines Lijphart's comparable cases research strategy (1975) with statistical methods. Important 
Table 1 Summary of hypotheses and operational definitions of variables

H Variable Effect Operational definition

\section{Institutional opportunity structure}

1.1 Task level: EU association +

1.2 Corporatism + Pluralism +

Resource dependencies

2.1 Relevance of EU institution

2.2 Policy information

2.3 Internationalization

2.4 Economic weight

2.5 Membership density

\section{Organization}

3.1 Sector domain

3.2 Federation Mixed membership

3.3 Budget

3.4 Interest representation

\section{Strategic choice}

4.1 Insider strategy

4.2 Outsider strategy

EU outsider strategy

4.3 Nationalistic strategy

$+$

$+$

$+$

$+$

$+$

0 (French associations), $1 \mathrm{EU}$ associations

0 (French associations), 1 German associations

0 (French associations), 1 UK associations

Relevance of EU institution (Commission, EP or EU Council) for interest representation from 1 (not important at all) to 6 (very important) Scale of providing political, legal, technical or economic policy information: 1 never; 2 sometimes; 3 often

$+\quad 1$ sub-sector; 2 sector; 3 cross-sector

+ $\quad 0$ (other members); 1 members: associations

$+\quad 0$ (other members); 1 members: firms and associations

$+\quad$ Revenue of the association in $€ 10,000$

$+\quad$ Percentage of revenues spent on interest representation

$+\quad$ Factor scores for the importance of personal contacts, position papers, administrative responsibilities

- $\quad$ Factor scores for the importance of media, public mobilization, presence in committees

$+\quad$ EU associations: factor scores for the importance of media, public mobilization, presence in committees

- $\quad$ Factor scores for the importance of nationality, language, party affiliation

Note: All variables are based on the questionnaire that was sent to the associations. Hence, the data in this article are based on the information and the assessments of the respondents.

context variables are controlled by focusing on a particular category of collective actors in EU member states with several common features. The crosssectional analysis is based on a survey conducted between June 1998 and 
March 1999. 4 The survey focused on two classes of actors. It addressed 1998 German, French, UK and EU business associations and asked them to specify their patterns of interest intermediation. In addition, 68 large firms in these countries were questioned. The firms are excluded from this analysis. ${ }^{5}$ Focusing on producer and employer associations means that a significant portion of the interest organizations active at the EU level are covered: about $80 \%$ of the EU associations are business interest associations (see European Commission, 2002b).

Owing to its large size and broad sectoral coverage, ${ }^{6}$ the analysis should give a good indication of the cumulative responses of business interests to European integration after almost 50 years of the integration process. But note that no time-series data are available (yet) on this topic and that only a few questions in the questionnaire cover the longitudinal comparison. Overall, 834 responses were received (see Table 2). Excluding international associations, the rate of return was $40.9 \%$, and the return rates for the different subgroups ranged from $32.3 \%$ in the case of the French associations to $50.0 \%$ in the case of large firms. Although providing a reasonable rate of return on which inferences can be based, the sample might disproportionately cover those organizations that are affected by EU regulation and have the capacity to deal with the EU institutions. I did not correct this by statistical weights because the structure of the European business interest group population is not well known. ${ }^{7}$

The focus on the large member states makes for variations among the domestic patterns of interest intermediation. Hence, it is reasonable to expect significant cross-national variation (see Hypothesis 1.2). At the same time, the choice of countries holds important background conditions fairly constant: these are the country size, the level of economic and technological development, the relevance of these countries in EU decision-making, their formal decision-making rights, and their long duration of EU membership. Therefore, the findings presented here cannot be easily translated into the contexts of the worse-off member states (Portugal, Spain and Greece) whose economic structures diverge somewhat, or into the contexts of those member states that joined the EU in 1995 (Sweden, Finland and Austria) because only then were these exposed to the full influence of the EU. Obviously, this holds all the more for the new member states of the Eastern enlargement.

\section{The regression analysis}

I analyse the impact of these factors by means of ordered logit regressions because access to the EU institutions was measured in six categories on an 
ordinal scale: no, annual, half yearly, quarterly, monthly, and weekly contacts. Table 3 describes the access of the business associations to the EU institutions. As discussed, the groups maintain more contacts with the Commission than with the Parliament, and slightly more contacts with the EP than with the EU Council. They are more frequently in touch with the working levels of the Commission and the Council than with the political leadership of these institutions. However, their access to the members and committees of the European Parliament is fairly similar. Hence, the vertical structures of the Commission and the Council account for several differences in the access patterns, whereas the horizontal division of labour between committee and plenary work in the Parliament does not cause much variation.

The bottom panel of Table 4 presents the summary statistics of the maximum likelihood estimations. ${ }^{8}$ The overall fit of the models can be gauged from the $G^{2}$ likelihood ratio tests, which are all statistically significant $(p<.001)$. According to McKelvey and Zavoina's $R^{2}$, the models explain between 46\% (Council of Ministers) and 59\% (Commission working level) of the variance if the ordinal data were transformed into an underlying interval scale. They predict between $46 \%$ (Commission working level) and $70 \%$ (Council of Ministers) of the cases correctly.

The top panel in Table 4 presents the regression results. Missing values were estimated by multiple imputation (Honacker et al., 2001; King et al., 2001) because a significant number of cases would have been lost using listwise deletion. Raw coefficients are ordered logit coefficients. The significance levels are based on two-tailed tests. Beyond their direction and significance, these coefficients are hard to interpret because the impact of a change in the value of an independent variable on the contact probabilities depends upon the values of all other independent variables. To facilitate their substantive interpretation, I discuss the outcomes for sector federations, with all other variables kept at their means or moved from their minima to their maxima. Figure 1 displays their contact probabilities with the political leaders and desk officers in the Commission and the Council of Ministers and with the members of the European Parliament, separately for EU groups and national associations, with all other independent variables kept at their means. Table 5 indicates the impact of moving an independent variable from its minimum to its maximum on the probability of having weekly contacts with these EU institutions, ${ }^{9}$ thus demonstrating its substantial effect. Contrasting EU associations with German groups, Figure 2 illustrates the effects of financial resources, institutional relevance and policy information on the contact probabilities with the EU bureaucracy when moved from their minima to their maxima. The vertical lines indicate the means of the variables. 


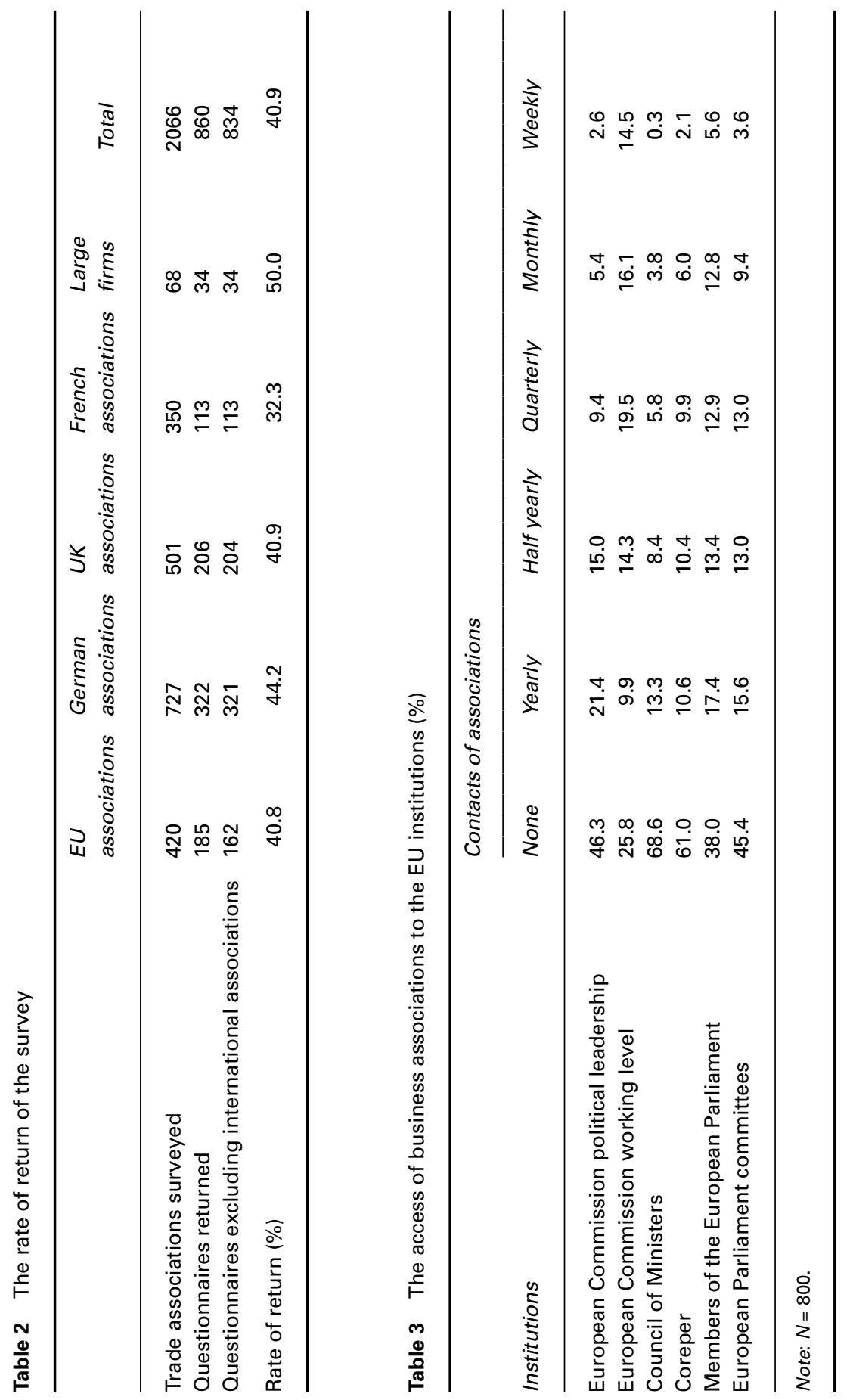




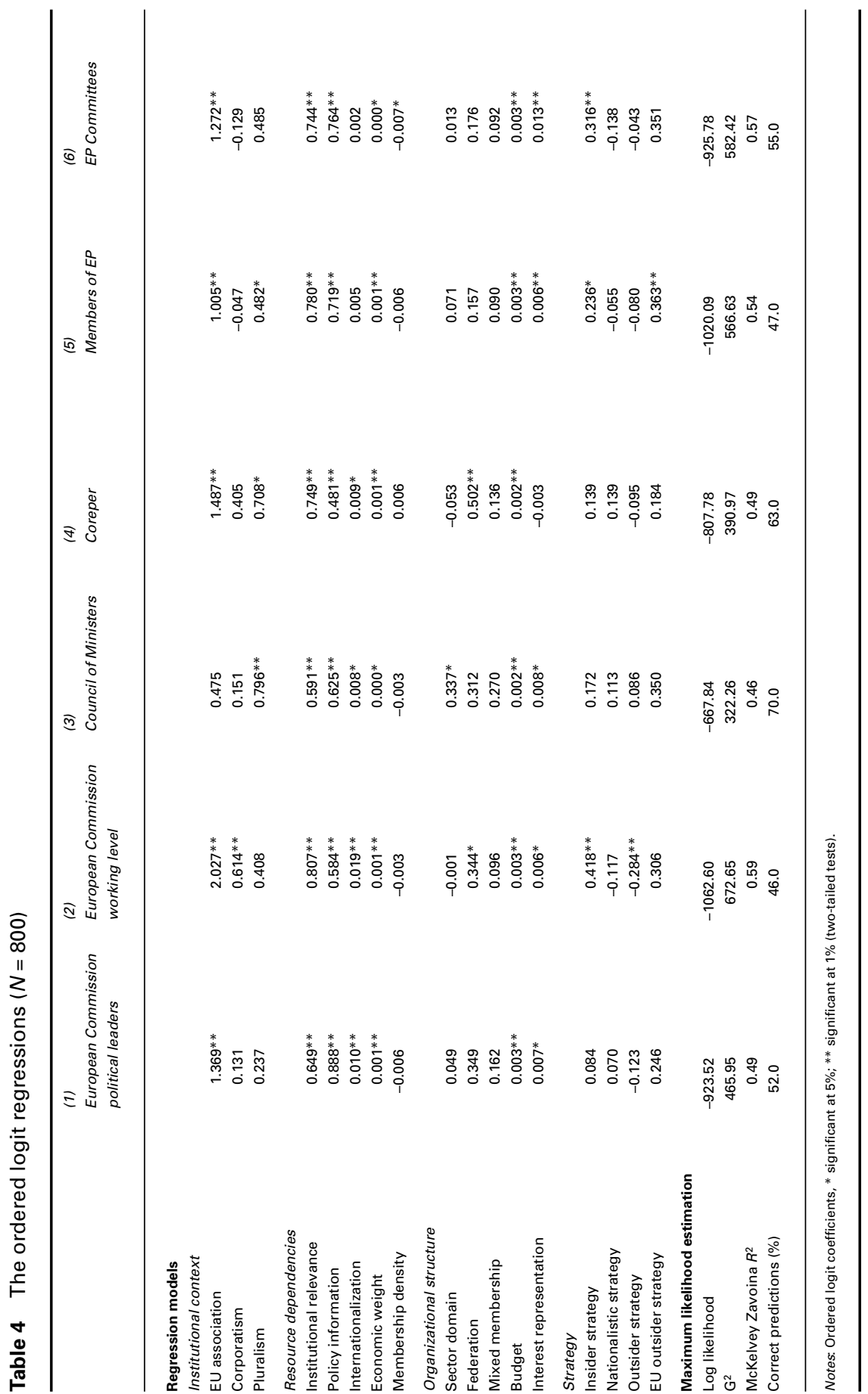




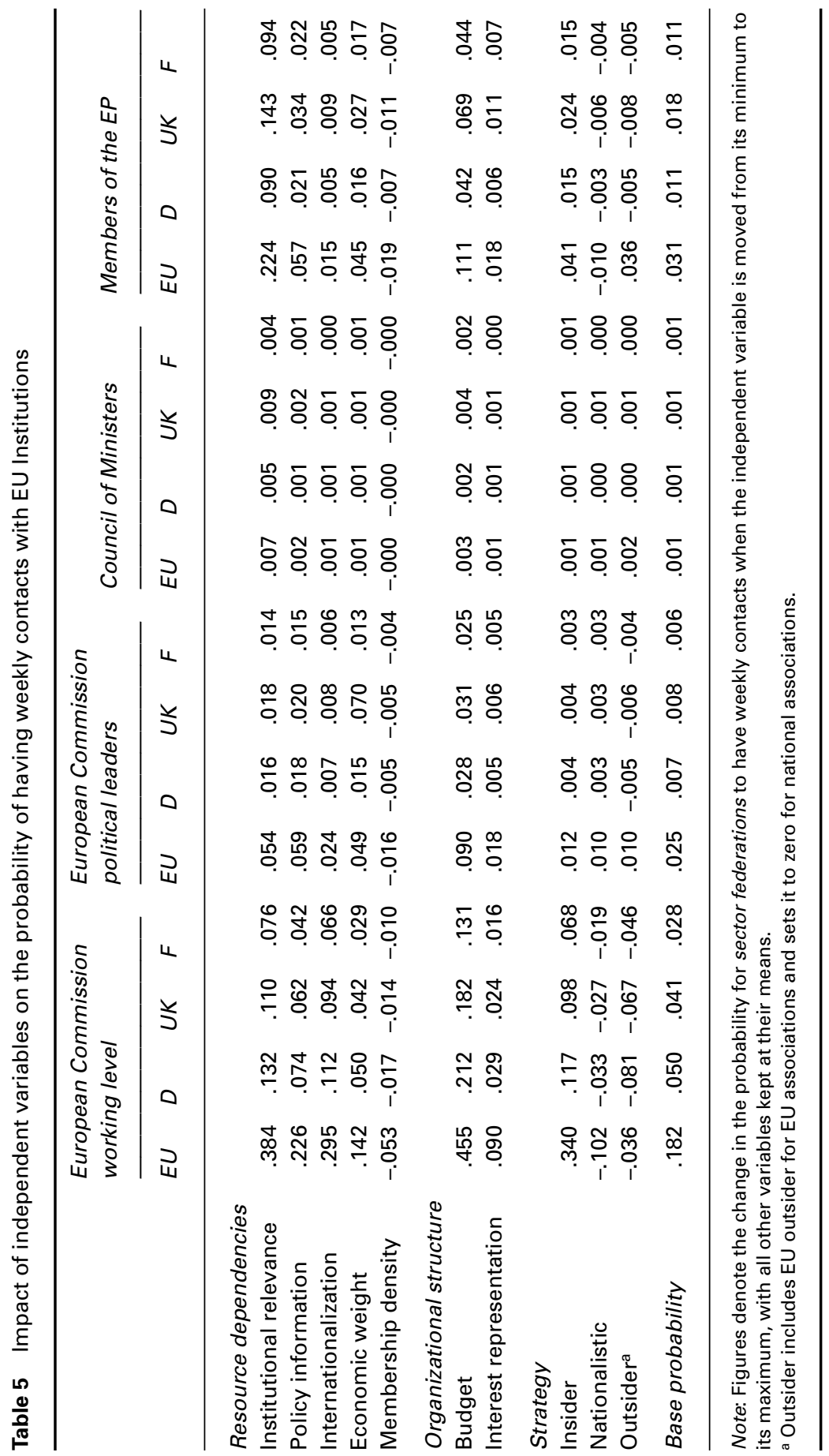



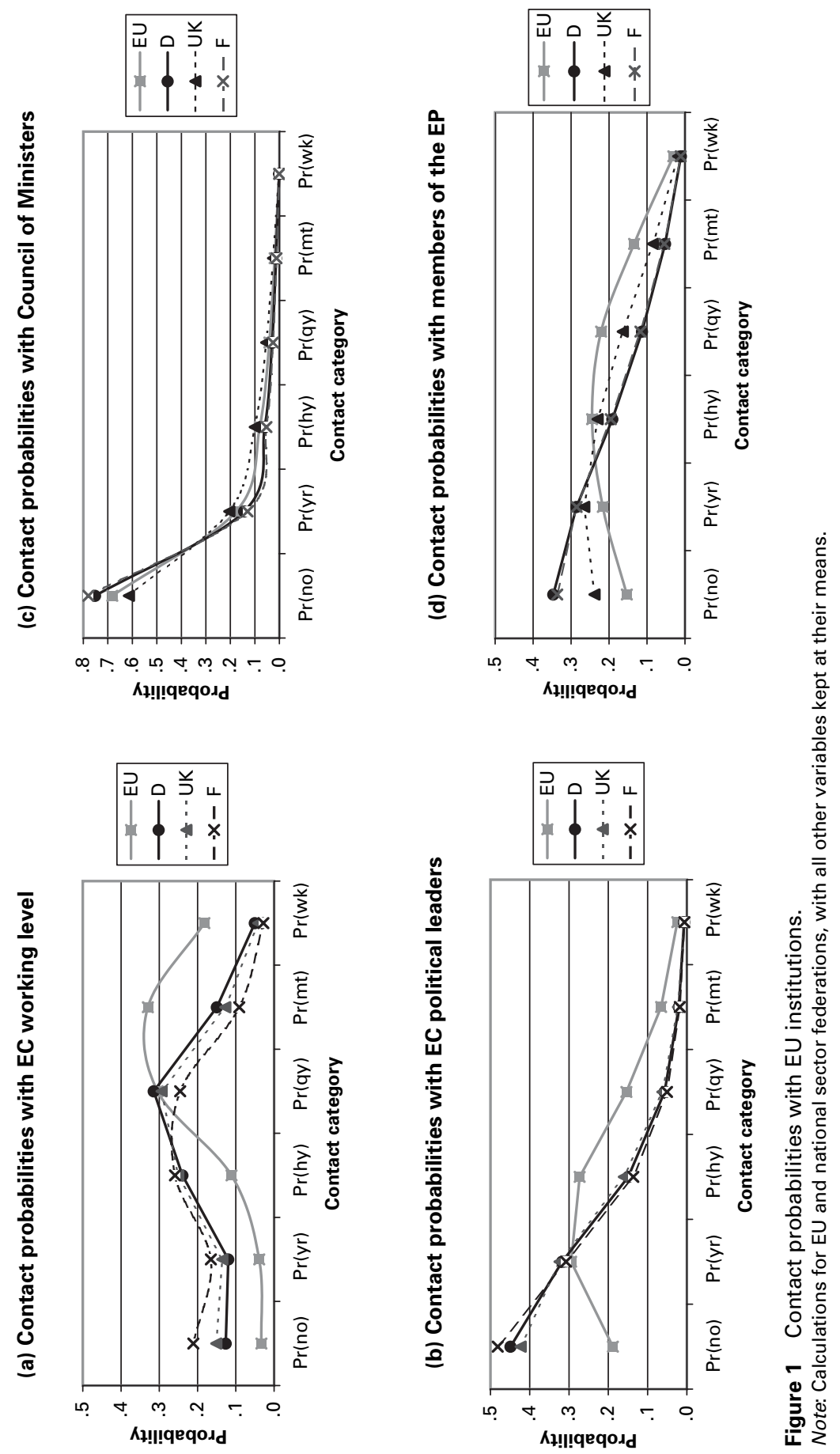


\section{(a) EU associations}
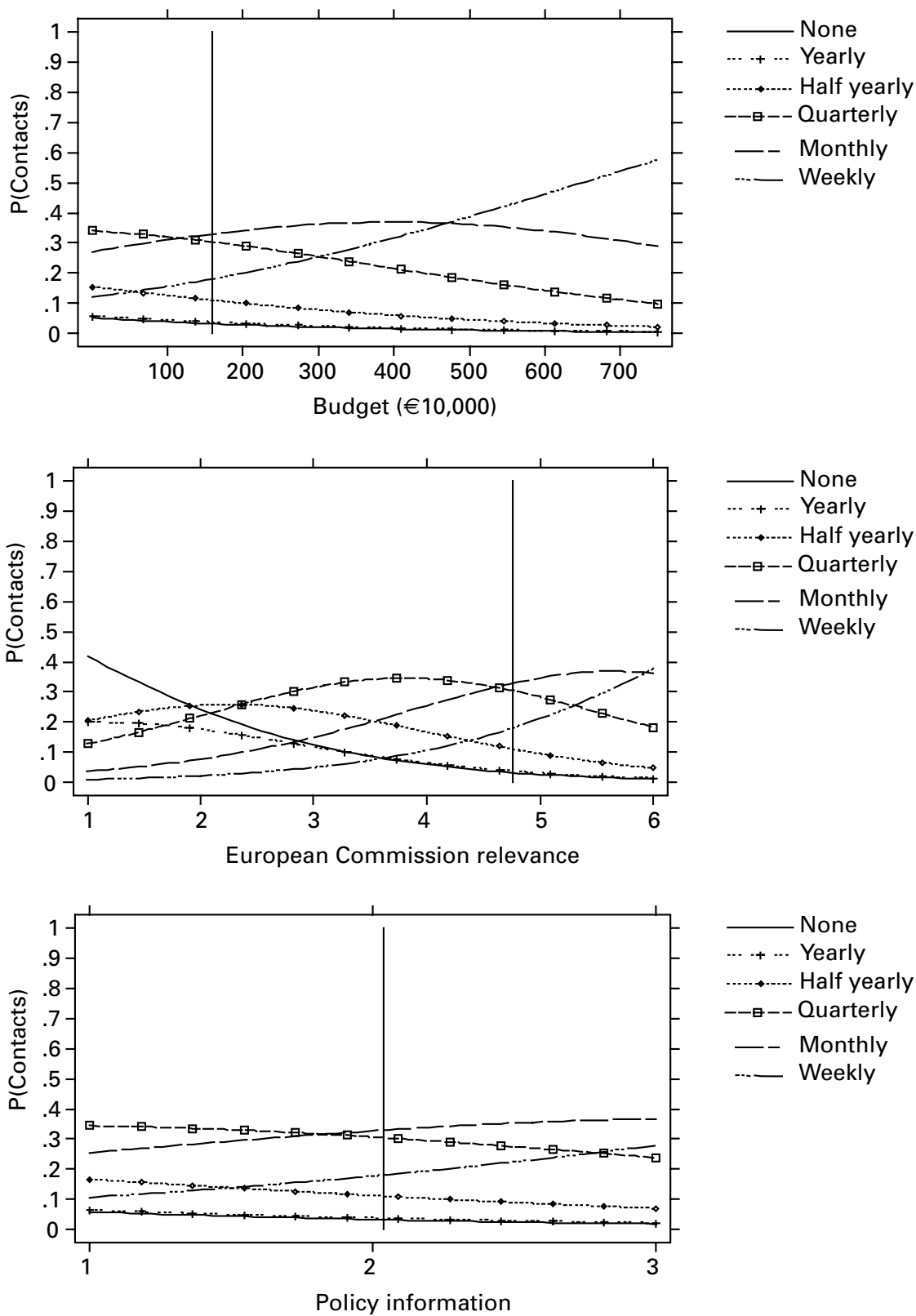

Figure 2 Contact probabilities with European Commission working level, conditional upon budget, relevance and policy information.

Notes: The figures denote the changes in the contact probabilities for sector federations when the independent variable is moved from its minimum to its maximum, with all other variables kept at their means. Vertical $x$-lines denote the means of the three variables. 
(b) German associations
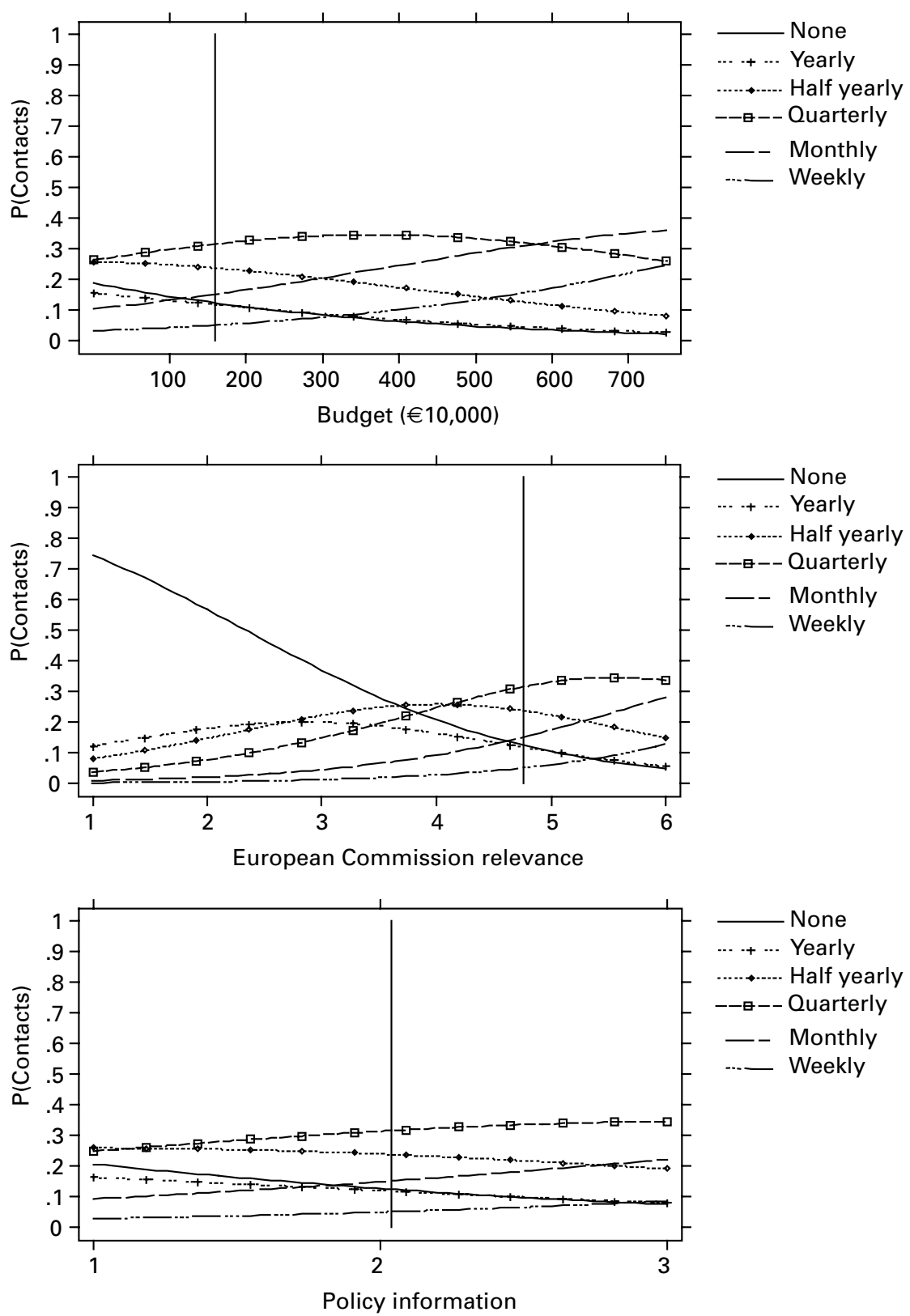

Figure 2 Continued 


\section{The empirical results: Access and explanations}

The empirical results confirm that the institutional context, resource dependencies, organizational structures and strategic choices must be taken into account when analysing the access of business interest organizations to the EU institutions. It is insufficient to focus on just one of these dimensions. Because the EU institutional context is highly segmented, EU interest intermediation is highly variegated. Only a few factors have a consistent impact on access patterns, namely the position of associations in the EU multi-level setting, the organizational resources they control and their perception of institutional regulation. The effects of all other factors are contingent upon the characteristics of the EU institutions.

\section{The institutional context}

Their location in the EU multi-level system has a significant impact on the contacts of interest organizations with the EU institutions. EU associations tend to have better access than national groups, which supports Hypothesis 1.1. According to Figure 1, this difference is most pronounced at the working level of the Commission and less obvious at the level of its political leaders and in the EP. The probability of EU associations maintaining weekly contacts with EU bureaucrats amounts to .18. While suggesting that only about one-fifth of EU groups tend to be in touch with the Commission very often, this figure is six times higher than that of French groups and three and a half times higher than that of German groups. The probability of EU groups maintaining weekly contacts with MEPs is rather low. It amounts to .03, which is still two to three times higher than that of the national groups (see the base probabilities in Table 5). In contrast to previous studies (Bouwen, 2002: 17, 24) claiming that national associations are as frequently in touch as EU-level groups with the Parliament, these figures illustrate that EU associations have become major interlocuters of both the Commission and the Parliament, whereas, on average, national associations are only occasionally in touch with these institutions. However, the EU groups find it as difficult as national associations to approach the Council because Council members represent national interests to a greater extent than do the other EU institutions. They also lack the additional national avenue to Council members that is open to national associations.

The multi-level structure of the institutional setting has a more profound impact than the domestic modes of interest intermediation. In fact, there is no clear-cut relation between these modes and the contact patterns at EU level. Figure 1 illustrates rather small and complex differences between the national groups: UK pluralism supports slightly better access than French 
statism to the EU Council and to the EP but not to the Commission. Corporatist practices enable German associations to establish more contacts with the Commission bureaucracy than the French associations but not with the other institutions. These findings are inconsistent with the expectation (Hypothesis 1.2) that there is a clear rank order between corporatist, pluralist and statist groups when it comes to representing interests at EU level. Nor do these findings support the proposition that the degree of fit determines the access of domestic interest groups.

Therefore, the rival hypothesis about the impact of the embeddedness of domestic actors in national policy networks needs to be scrutinized. A closer inspection (appendix Table A2) ${ }^{10}$ yields moderate to strong correlations between the domestic and the EU-level contacts of national interest groups. Accordingly, it can be ruled out that weak embeddedness in national politics provides the grounds for close relations with the EU institutions. On the contrary, domestic embeddedness tends to reinforce access at the EU level. This correlation is strongest among the German groups, which translate the corporatist division of labour between peak associations and other interest groups to the EU level. In pluralist and statist regimes, in contrast, the domestic division of labour is under greater pressure.

Thus, the modes of interest intermediation do not result in consistent access patterns at EU level. However, they condition the impact of the EU on the division of labor and the mode of competition in the domestic interest group systems. Finally, when analysing the predicted access patterns by country, the French and particularly the UK organizations appear to incorporate the European Parliament to a greater extent into their lobbying strategies than do the German associations. These concentrate their efforts on the EU bureaucracy, apparently transferring their domestic focus on administrative interest intermediation to the EU level (Dyson, 1980; Lehmbruch, 1991).

However, when disaggregating the empirical contact patterns by country (not reported), German associations maintain slightly more contacts than UK or French groups with the Commission and have as many contacts as UK associations with the EU Council and the EP. According to the regression results, UK associations would be expected to have better access to these institutions, apart from the EU bureaucracy. Here, the exchange goods, the organizational resources and the strategies of the interest groups come into play, outweighing the effects of the modes of interest intermediation. German associations tend to have broader domains and more resources than UK organizations, specialize more in interest representation, and are more likely to pursue insider strategies. They control more policy information and find the EU institutions to be more important for the representation of their interests. All together, these factors outweigh the domestic modes of interest 
intermediation, which therefore seem to be less relevant to the explanation than organizational structures, resources and strategies. Research on large firms corroborates the inconsistent impact of these modes on EU lobbying (Bernhagen and Mitchell, 2007).

\section{Resource dependencies}

Resource dependencies are crucial to the explanation of access patterns. The relevance that associations ascribe to the EU institutions because of their political activities has a profound impact on the contact frequencies, as was expected in Hypothesis 2.1. In fact, national associations are not likely to seek access if an EU institution seems irrelevant to the representation of their interests. For example, in that case, the likelihood of German associations not maintaining contacts with the Commission amounts to a striking $75 \%$ (Figure 2). If they find the EU bureaucrats highly relevant to their cause, the German groups are most likely to have quarterly access to them.

The perception of the EU institutions also shapes the activities of the EU-level groups. Their probability of maintaining weekly contacts with EU bureaucrats increases by 38 percentage points if they attach great rather than little importance to the EU officials for the representation of their interests (Table 5). Even though the likelihood that associations maintain as many contacts with MEPs is well below these levels, the Parliament appears also to be quite open to major stakeholders in EU policies. Perceiving the Parliament as a very important institution tends to enhance the probability of having weekly contacts with it more than any other factor does (see Table 5).

Furthermore, the exchange goods that interest organizations control are of major importance. As expected, the ability to provide policy information improves their access, corroborating that this capacity is important in EU politics (Hypothesis 2.2). The probability of EU groups having weekly contacts with EU bureaucrats increases by .23 and that of German groups is raised by .07 if they command a maximum rather than a minimum of policy information (Table 5). However, compared with the importance that interest groups ascribe to the EU institutions, their capacity to provide policy information has a more moderate effect on access patterns (see Figure 2). More generally, policy information does not seem to be as important for obtaining access as has been suggested in earlier studies (Bouwen, 2002). However, this finding does not rule out that policy information may be crucial when it comes to securing policy outcomes.

In support of Hypothesis 2.4, greater economic weight increases contact frequency. The EU institutions cannot ignore the employment effects of European policies and they include groups that have economic clout more 
frequently in their political consultations. However, the number of employees in the member firms that an association represents appears to be less relevant to the explanation of the contact patterns than the importance that groups ascribe to the EU institutions and their ability to provide policy information. The probability of EU groups having weekly contacts with the EU bureaucracy increases by .14 and that of national groups is raised by .03 to .05 if their members have 1.5 million employees rather than none.

The remaining two exchange goods vary in their effects across the EU institutions. As expected (Hypothesis 2.3), internationalization enables interest organizations to establish more contacts with the EU Council and the Commission. The likelihood of EU groups maintaining weekly contacts with EU bureaucrats increases by almost 30 percentage points if the firms they represent are highly internationalized (Table 5) and not confined to a national market. However, internationalization does not support significantly better access to the Parliament. Depending on the support of their constituencies, the MEPs pay as much attention to domestic business as to multinational enterprises. In conclusion, the Parliament should prove to be more responsive to protectionist demands than the Council or the Commission.

Finally, greater membership density does not have a significant impact on the number of contacts with the Commission and the Council. In stark contrast to Hypothesis 2.5, it even reduces the odds of having contacts with the EP. There are two reasons why there appears to be no real pull from the EU institutions to consult business associations that seem more representative of their domains. First, except for the social partners, the EU institutions have not yet developed clear standards as to what determines the representative character of an association. Hence, they might not be aware of the membership density of associations. Second, other exchange goods seem to be of greater importance to the EU institutions when it comes to consulting business associations: they tend to consult groups that represent European rather than national interests, are stakeholders in EU regulation and can provide policy information or have economic clout.

\section{Interest group organization}

Among the organizational factors, the financial resources of interest organizations are of major importance. The probability of EU associations that are in command of considerable financial resources (i.e. a budget of 7.5 million) having weekly contacts with the Commission is 46 percentage points higher than that of have-nots (Table 5 and Figure 2), which supports Hypothesis 3.3. The corresponding increases for national associations range from 13 percentage points (French groups) to 21 percentage points (German groups). Of all 
factors, then, the financial endowment of groups has the greatest potential to leave an imprint on contacts with the Commission, and when it comes to accessing the Council and the Parliament it ranks second only to the importance that associations ascribe to these institutions. However, associations that want to 'buy' more contacts with the EU institutions need to invest heavily in their lobbying activities: increasing the associational budget from the overall mean of 1.59 million by 250,000 raises the probability of EU associations having weekly contacts with the Commission by just 1 percentage point and that of national groups by 0.2 to 0.5 percentage points (see Table 5 or Figure 2).

Specializing in interest representation also pays off, improving the ability of groups to address the relevant contact partners and to deliver the requested exchange goods (Hypothesis 3.4). But the extent to which groups concentrate on the representation of interests is less consequential than the material resources at their disposal. The probability of EU groups having weekly contacts with the Commission bureaucracy is raised by 9 percentage points when fully concentrating on interest representation rather than on the coordination of markets or the provision of services.

The sector domain and the position of associations in the associational systems have ambiguous effects, reflecting both institutional variations and the contradictory logics built into these factors: associations with broader sector domains tend to have slightly better access to the Council than groups with narrower domains (Table 4). The national ministers prefer to listen to broad-based interest groups that are affected by a large number of EU policy issues and represent a broad membership. However, in contrast to Hypothesis 3.1, these organizations are not more frequently in touch with the other EU institutions. Evidently, the policy experts in the Commission and the Parliament depend as much on the input of more specialized associations, which also suffer less from collective action problems.

Being located at the higher echelons of the associational population, federations are more frequently in touch with the Commission and with Coreper than are groups with a direct membership. But this does not hold for groups with a mixed membership, which invalidates Hypothesis 3.2. The European Parliament, which might be expected to support broad-based political representation throughout the Union, rewards neither greater domain size nor a peak association function. In sum, the Council machinery has a preference for dealing with associations that are located at the peak of their domain or have a broad-based domain, whereas the Commission privileges peak associations. None of these associational properties is of relevance to the MEPs. 


\section{The strategic choices of interest organizations}

Finally, the strategies that interest organizations pursue matter, even though a few caveats are in order. First, nationalistic strategies have no significant effects, thus invalidating Hypothesis 4.3. Second, the impact of insider and outsider strategies is contingent upon the institutional context, which is contrary to Hypotheses 4.1 and 4.2: they affect neither the number of contacts with the Council and its administration nor those with the Commission leaders. Nonetheless, these strategies have a significant bearing on access to policy experts in the Commission and in the Parliament.

As expected, an insider strategy improves access to both parliamentarians and bureaucrats. It has a profound impact on the number of contacts that interest groups maintain with the EU bureaucracy. Relying greatly on an insider strategy rather than not relying on insider tactics increases the probability of EU groups maintaining weekly contacts with EU bureaucrats by .34 and that of national groups by .07 (French associations) to .12 (German groups) (see Table 5). Hence, the insider strategy proves to be a highly efficient means of communicating policy information to the bureaucratic staff when policy proposals are being drafted. It is of less relevance when the organizations seek to approach the Parliament on a regular basis, but even here it is still more effective than an outsider strategy.

The impact of the outsider strategy varies, which highlights important institutional differences. Under public scrutiny, the members of the European Parliament are attentive to media coverage and public debates. That is why national associations that pursue an outsider strategy do not have fewer contacts with the MEPs and why EU associations employing outsider tactics across national borders have even more contacts with them. This suggests that national groups use outsider strategies mainly in order to draw public or governmental attention to EU policies. They rely on the mobilization of domestic publics and politicians as well as on the activities of EU-level groups but do not necessarily seek redress through the European Parliament. In contrast, EU associations tend to combine outsider strategies with a greater presence in parliamentary consultations. The bureaucratic rationality of the Commission staff clearly diverges from the Parliament's response to EU media coverage. Pursuing an outsider strategy tends to reduce access to the bureaucratic staff. On the one hand, groups pursuing outsider tactics use it to compensate for a lack of access to the EU bureaucracy; on the other hand, these tactics also interfere with the logic of the insider strategy. Hence, it seems possible to combine insider and outsider strategies vis-à-vis the Parliament but not vis-à-vis the Commission. This might place interest groups in a dilemma because it seems difficult to limit the effects of outsider strategies to specific institutions in a political system. 


\section{Conclusion}

EU political exchanges are shaped by institutional context and resource dependencies as well as by the organizational structures and strategic choices of interest groups. It would be remiss to exclude either of these dimensions from the study of interest group access in the EU. Studies focusing on just one of these dimensions tend to overrate its importance. Nonetheless, the analysis confirms that it is difficult to identify general patterns of interest intermediation in the EU because the impact of many factors is conditioned by the segmented EU institutional context.

Several findings about the general determinants of EU interest intermediation consolidate the results of previous studies. To some extent, they modify our conventional wisdom and also establish the relative importance of these factors. First, EU regulation is a major incentive for associations to intensify their lobbying efforts and to get in touch more frequently with the EU institutions. It is indeed necessary for national associations to locate the EU institutions important for the representation of their interests if they are to establish contacts with them. The Commission and the Parliament prove to be quite open to those interest groups that are affected by EU regulation and that consider them to be important.

Secondly, in the EU multi-level setting, EU and national associations act primarily at their main level of operation and have developed a division of labour that extends to different phases of the policy cycle: EU associations concentrate their activities on its early stages, whereas national groups tend to follow the process from the formulation of EU policies until their implementation in the member states. All in all, EU associations have evolved into routine interlocuters of the EU institutions when EU policies are being drafted. To say the least, they have turned into important negotiation arenas, and in some cases even into actors in their own right. By contrast, only a minority of national associations act routinely at the EU level. Because these actors are usually also well embedded in domestic policy networks, they are vital to the representation of business interests in the EU multi-level system (Eising, 2004).

Thirdly, resources are crucial to the representation of interests in EU politics. Well-endowed associations have much better access than poor associations, underscoring that EU lobbying needs substantial material backing. The ability to provide policy information also improves the standing of interest groups even though it appears to be less important for obtaining access than has been suggested in previous studies (Bouwen, 2002). Moreover, EU state-group relations are clearly not confined to the exchange of policy information. Economic clout and internationalization have also proven to be of some importance because the $\mathrm{EU}$ institutions must take the economic effects of EU policies into account. 
In sum, those organizations that find the EU institutions important to the representation of their interests, command sufficient financial resources, can bring in policy information and have economic clout tend to have better access than other groups, which gives them a greater chance to have a say in EU policies. The significance of political exchange goods and material resources in EU politics raises genuine doubts that the current efforts of the EU institutions at strengthening civil society participation and working towards more equitable consultation patterns (see European Commission, 2002a) will significantly reduce the bias that exists in favour of resourceful actors. For this to happen, not only would the EU institutions need to pay a substantially higher premium on interest groups' other exchange goods, such as their potential contribution to policy legitimacy and public support for the EU. Civil society organizations would also need to be able to follow EU policy issues across the policy cycle and table detailed policy information that is backed by large constituencies.

In that respect, it is important to note that, among the EU institutions, only the European Parliament is attentive to outsider strategies enhancing the public debate. The political rationality of the MEPs, who are subject to national election pressures, clearly differs from the bureaucratic rationality of the Commission, which encourages an insider strategy and punishes an outsider strategy in its attempt to devise innovative and workable policy proposals. It appears that the Parliament is a more promising venue for civil society concerns and protectionist demands than the Council or the Commission, even though it is important to bear in mind that it still has limited legislative powers (see also Kohler-Koch, 1997). As a consequence, national groups use outsider tactics mainly to draw public or governmental attention to their causes and rarely seek redress through the Parliament. EU associations, in contrast, tend to combine such tactics with a greater presence in parliamentary consultations.

Finally, the relationship between national modes of interest intermediation and EU access patterns is less pronounced than was posited in earlier studies (Cowles, 2001; Schmidt, 1999). The differences among statist, pluralistic and corporatist groups were both smaller and more complex than expected. There are several explanations for the resulting ambiguity. First, factors other than these national modes may be more important in EU politics. In part, organizational structures, strategies and exchange goods outweigh their impact. Second, the domestic modes may be less different than is often claimed. It is likely that, after 50 years, European integration has levelled out some differences. Moreover, these modes are rarely found in their pure form, rather often being blurred. Finally, the modal studies have not paid much attention to institutional differentiation, which is of great importance in this study. 
Given these results and the limitation of this study to the analysis of business interests from three large EU member states, three major research desiderata emerge. First, it would be useful to subject other types of interest organizations, a broad variety of policy issues and a greater number of EU member states to quantitative analyses in order to place our understandings of EU interest intermediation on a more robust empirical basis (see the contributions in Coen, 2007). Second, in conjunction with the importance of multilevel policy networks, the segmentation of the EU institutional setting calls for systematic comparisons of these structures in different issue areas. Such analyses should explicitly address those theoretical and empirical gaps that can best be tackled in configurative analyses. Finally, the focus of EU interest group studies needs to be broadened to incorporate the study of social movements, political cleavages and political parties, which are all part of the political space in which interest groups are situated. This might help place political scientists in a position to come to terms with major aspects of the cleavage structure and the democratic quality of the European polity.

\section{Notes}

The paper draws on survey research conducted at the Mannheim Centre for European Social Research with Christine Quittkat and directed by Beate KohlerKoch. I am grateful for the financial support provided by the European Centre for Public Affairs and the University of Mannheim, as well as for the chance to conceive the initial parts of this study at the European University Institute. Earlier versions of the paper were helpfully discussed at the European Union Studies Associations Conference in Austin, at the European Consortium for Political Research General Conference in Budapest, at the FernUniversität in Hagen, in the ARENA seminar series in Oslo, and at the Economic and Social Research Council workshop on 'Organized Interests and Democratic Governance' in Newcastle. In particular, I would like to thank Nathalie Behnke, Arthur Benz, Jan Beyers, David Coen, Maria Green Cowles, Andrea Lenschow, David Lowery, Susanne Lütz, Gary Marks, Johan P. Olsen, Vivien Schmidt, Gerald Schneider, Ulf Sverdrup, Tony Zito and three anonymous referees for their insightful suggestions.

1 The situation is similar in US interest group studies (see Baumgartner and Leech, 1998).

2 EURELECTRIC, the peak association of the EU electricity industry, complained that it was temporarily shut out from EU decision-making when the European Commission drafted its proposals for the liberalization of the sector.

3 Corporatism is measured by a dummy variable for German associations, and pluralism is measured by a dummy variable for UK associations. French associations are the reference category. As a result, French groups are also the reference category for the effect of the task level, which compares EU associations with national associations. To assess the difference between EU and 
national associations, I take the sizes of the regression coefficients in the subsequent analysis into account.

The policy information scale is based on three variables that indicate how often (never, sometimes, often) associations are asked to provide legal, economic or political information to political institutions (Cronbach's alpha: .68).

The three strategy factors were extracted from 11 variables by means of a principal components analysis. These variables indicate either the importance of different criteria for selecting contact partners (nationality, language, administrative responsibility, party membership) on a scale from 1 (not at all important) to 6 (very important) or the usefulness of different ways of representing interests (position papers, personal contacts, regular contacts and background information, targeted contacts and information, presence in committees and hearings, scientific expertise, mobilization of public and media) at EU level. The three factors cover $62 \%$ of the total variance. 'Insider strategy' has an Eigenvalue of 4.0 and extracts $36 \%$ of the variance, 'nationalistic strategy' has an Eigenvalue of 1.7 and extracts $16 \%$, and 'outsider strategy' has an Eigenvalue of 1.0 and extracts $9 \%$. Since these strategies need not be mutually exclusive, an oblique rotation was performed. 'Insider strategy' loads highly on administrative responsibilities and personal contacts and moderately on committee presence and scientific expertise. 'Nationalism' loads highly on nationality and language and to a lesser extent on party membership. 'Outsider strategy' loads highly on committee presence, scientific expertise and mobilization of media and public; it is moderately correlated with 'insider strategy' (Pearson's $r$ : .40).

4 The sample is based on the following sources: Oeckl (1997), Conseil National du Patronat Francais (1997), Henderson and Henderson (1995), European Commission (1996).

5 I compare the access of business associations and large firms elsewhere (Eising, 2007).

6 Economic branches from agriculture, industry and services are included. The largest branch is trade, with a share of $13.8 \%$ of all associations.

7 As a consequence, the data might underrate the empirical variance within the interest group population, and the subsequent regression analysis might, to some extent, underplay those factors that bear significantly on the access patterns.

8 I used SPost (Long and Freese, 2001) to calculate these measures and the resulting probabilities.

9 Table A1 (in the appendix) provides the descriptive statistics of these variables.

10 The appendix is available at http://www.uni-konstanz.de/eup/issues.htm.

\section{References}

Baumgartner, Frank and Beth Leech (1998) Basic Interests: The Importance of Groups in Politics and in Political Science. Princeton, NJ: Princeton University Press.

Bennett, Robert J. (1997) 'The Impact of European Economic Integration on Business Associations: The UK Case', West European Politics 20(3): 61-90. 
Beyers, Jan (2002) 'Gaining and Seeking Access: The European Adaptation of Domestic Interest Associations', European Journal of Political Research 41(5): 585-612.

Bernhagen, Patrick and Neil Mitchell (2007) 'Transnational Business Actors and Lobbying in the European Union', Paper presented at the ESRC Workshop 'Organized Interests and Democratic Governance', Newcastle, 25-26 January.

Bouwen, Pieter (2002) 'A Comparative Study of Business Lobbying in the European Parliament, the European Commission and the Council of Ministers', Max-Planck-Institut für Gesellschaftsforschung Discussion Paper 02/7.

Coen, David (1998) 'The European Business Interest and the Nation State: LargeFirm Lobbying in the European Union and Member States', Journal of Public Policy 18(1): 75-100.

Coen, David (ed.) (2007) 'The Empirical Study of Interest Groups in the European Union', Journal of European Public Policy (Special Issue) 14(3).

Conseil National du Patronat Francais (1997) Annuaire Officiel 1997, Paris: CIRNOV SA.

Constantelos, John (1996) 'Multi-level Lobbying in the European Union: A Paired Sectoral Comparison across the French-Italian Border', Regional and Federal Studies 6(1): 28-55.

Cowles, Maria Green (2001) 'The Transatlantic Business Dialogue and Domestic Business-Government Relations', in Maria Green Cowles, James A. Caporaso and Thomas Risse (eds) Transforming Europe: Europeanization and Domestic Change, pp. 159-79. Ithaca, NY: Cornell University Press.

Crombez, Christophe (2002) 'Information, Lobbying and the Legislative Process in the European Union', European Union Politics 3(1): 7-32.

Dyson, Kenneth (1980) The State Tradition in Western Europe. Oxford: Martin Robertson.

Dür, Andreas and Dirk De Bièvre (2007) 'The Question of Interest Group Influence', Journal of Public Policy 27(1): 1-12.

Eising, Rainer (2004) 'Multilevel Governance and Business Interests in the European Union', Governance: An International Journal of Policy, Administration and Institutions 17(2): 211-45.

Eising, Rainer (2006) 'Interest Groups and Social Movements', in Paolo Graziano and Maarten P. Vink (eds) Europeanization: New Research Agendas, pp. 167-81. New York: Palgrave Macmillan.

Eising, Rainer (2007) 'The Access of Business Interests to EU Institutions: Towards Elite Pluralism?', Journal of European Public Policy 14(3): 384-403.

European Commission (ed.) (1996) Directory of Interest Groups. Luxembourg: Office for Official Publications of the EC.

European Commission (2002a) Communication from the Commission: Towards a Reinforced Culture of Consultation and Dialogue - General Principles and Minimum Standards for Consultation of Interested Parties by the Commission. COM(2002) 704 final, Brussels, 11 December 2002.

European Commission (2002b) CONECCS Database. Brussels: European Commission General Secretariat.

Falkner, Gerda (2000) 'Policy Networks in a Multi-Level System: Convergence towards Moderate Diversity?', West European Politics 23(4): 94-121. 
Grande, Edgar (1996) 'The State and Interest Groups in a Framework of MultiLevel Decision Making: The Case of the European Union', Journal of European Public Policy 3(3): 318-38.

Greenwood, Justin and Mark Aspinwall (eds) (1998) Collective Action in the European Union: Interests and the New Politics of Associability. London: Routledge.

Grote, Jürgen and Achim Lang (2003) ‘Europeanization and Organizational Change in National Trade Associations: An Organizational Ecology Perspective', in Kevin Featherstone and Claudio Radaelli (eds) The Politics of Europeanization, pp. 225-54. Oxford: Oxford University Press.

Hall, Peter A. and David Soskice (eds) (2001) Varieties of Capitalism: The Institutional Foundations of Comparative Advantage. Oxford: Oxford University Press.

Henderson, S.P.A. and A.J.W. Henderson (eds) (1995) Directory of British Associations and Associations in Ireland, 12th edn. Beckenham: CBD Research.

Hollingsworth, J. Rogers and Robert Boyer (eds) (1997) Contemporary Capitalism: The Embeddedness of Institutions. Cambridge: Cambridge University Press.

Honacker, James, et al. (2001) Amelia: A Program for Missing Data. Cambridge, MA: Harvard University. URL (accessed November 2003): http:// GKing.Harvard.edu.

Hooghe, Liesbeth (2001) The European Commission and the Integration of Europe: Images of Governance. Cambridge: Cambridge University Press.

Imig, Doug and Sid Tarrow (eds) (2001) Contentious Europeans: Protest and Politics in an Emerging Polity. Lanham, MD: Rowman \& Littlefield.

King, Gary, et al. (2001) 'Analyzing Incomplete Political Science Data: An Alternative Algorithm for Multiple Imputation', American Political Science Review 95(1): 49-68.

Knoke, David (1990) Organizing for Collective Action: The Political Economies of Associations. Hawthorne, NY: Aldine de Gruyter.

Kohler-Koch, Beate (1997) 'Organized Interests in the EC and the European Parliament', European Integration online Papers 1(9). URL: http:/ / www.doaj.org/ ftxt/eiop.or.at/eiop/texte/1997-009.htm.

Lehmbruch, Gerhard (1991) 'The Organization of Society, Administration Strategies, and Policy Networks: Elements of a Development Theory of Interest Systems', in Roland M. Czada and Adriene Windhoff-Héritier (eds) Political Choice: Institutions, Rules, and the Limits of Rationality, pp. 121-58. Frankfurt a. M.: Campus.

Lijphart, Arendt (1975) 'The Comparable-Cases Strategy in Comparative Research', Comparative Political Studies 8(2): 158-77.

Lindblom, Charles (1977) Politics and Markets: The World's Political-Economic Systems. New York: Basic Books.

Long, John Scott and Jeremy Freese (2001) Regression Models for Categorical Dependent Variables Using Stata. College Station, TX: Stata Press.

Lowery, David (2007) 'Why Do Organized Interests Lobby? A Multi-Goal, MultiContext Theory of Lobbying', Polity 39(1): 29-54.

Mahoney, Christine (2004) 'The Power of Institutions: State and Interest Group Activity in the European Union', European Union Politics 5(4): 441-66.

Majone, Giandomenico (ed.) (1996) Regulating Europe. London: Routledge.

Marks, Gary and Doug McAdam (1996) 'Social Movements and the Changing 
Structure of Opportunity in the European Union', West European Politics 19(2): 164-92.

Mazey, Sonia P. and Jeremy J. Richardson (2002) 'Pluralisme ouvert ou restreint? Les groupes d'intérêt dans l'Union européenne', in Richard Balme, Didier Chabanet and Vincent Wright (eds) L'Action collective en Europe/Collective Action in Europe, pp. 123-61. Paris: Presses de Science Po.

Meynaud, Jean and Dusan Sidjanski (1971) Les Groupes de pression dans la Communauté Européenne 1958-1968. Structure et action des organisations professionnelles. Brussels: Institut d'Etudes Européennes; Université de Bruxelles.

Oeckl, Albert (ed.) (1997) Taschenbuch des öffentlichen Lebens. Deutschland, 46. Jahrgang. Bonn: Festland Verlag.

Olson, Mancur (1965) The Logic of Collective Action. Cambridge, MA: Harvard University Press.

Pollack, Mark A. (1997) 'Representing Diffuse Interests in EC Policymaking', Journal of European Public Policy 4(4): 572-90.

Schmidt, Vivien (1999) 'National Patterns of Governance under Siege: The Impact of European Integration', in Beate Kohler-Koch and Rainer Eising (eds) The Transformation of Governance in the European Union, pp. 155-72. London: Routledge.

Schmitter, Philippe C. and Wolfgang Streeck (1981) 'The Organization of Business Interests. A Research Design to Study the Associative Action of Business in the Advanced Industrial Societies of Western Europe', Discussion Paper IIM/LMP 81/13. Berlin: Wissenschaftszentrum Berlin.

Streeck, Wolfgang (1999) Korporatismus in Deutschland: Zwischen Nationalstaat und Europäischer Union. Frankfurt a. M.: Campus.

Truman, David B. (1951) (1993). The Governmental Process: Political Interests and Public Opinion. Berkeley: University of California. Institute of Governmental Studies.

Vogel, David (1987) 'Political Science and the Study of Corporate Power: A Dissent from the New Conventional Wisdom', British Journal of Political Science 17(4): 385-409.

Walker, Jack (1991) Mobilizing Interest Groups in America: Patrons, Professions, and Social Movements. Ann Arbor: University of Michigan Press.

Wilson, James Q. (1973) Political Organizations. New York: Basic Books.

Woll, Cornelia (2006) 'Lobbying in the European Union: From Sui Generis to a Comparative Perspective', Journal of European Public Policy 13(3): 456-69.

\section{About the author}

Rainer Eising is Professor of European Studies, Friedrich-Schiller University of Jena, Fuerstengraben 1, Jena, D-07743 Germany.

Fax: +493641945432

E-mail: rainer.eising@uni-jena.de 